\title{
Can Nocturnal Acid-breakthrough Be Reduced by Long-acting Proton Pump Inhibitors?
}

\author{
Hye Kyung Jeon and Gwang Ha Kim* \\ Department of Internal Medicine, Pusan National University School of Medicine, and Biomedical Research Institute, Pusan National University \\ Hospital, Busan, Korea
}
Article: Esophageal acidification during nocturnal acid-breakthrough with ilaprazole versus omeprazole in gastroesophageal reflux disease
Karyampudi A, Ghoshal UC, Singh R, Verma A, Misra A, Saraswat VA
(J Neurogastroenterol Motil 2017;23:208-217)

Gastroesophageal reflux disease (GERD) is a condition characterized by reflux of the gastric contents causing troublesome symptoms and complications. ${ }^{1}$ Proton pump inhibitors (PPIs) are the mainstay of treatment for GERD and significantly decrease gastric acid secretion. In spite of their potent acid suppression, PPIs cannot eliminate intragastric acidity, particularly during the night. PPIs have a relatively short plasma half-life and all proton pumps are not active at the same time. Therefore, during the night, the morning dosed PPIs are no longer effective on acid suppression of newly activated proton pumps. During the night, there is no gravity-mediated drainage and significant reduction in swallows; thus, reflux episodes are of longer duration. ${ }^{2}$ Based on these circumstances, nocturnal acid-breakthrough (NAB) has been the subject of attention to describe refractory GERD. NAB was first described as a decrease in gastric $\mathrm{pH}$ less than 4 for at least 60 consecutive minutes in the overnight period in patients on twice-daily PPIs treatment.

Originally, the rationale behind measuring intragastric $\mathrm{pH}$ and presence of $\mathrm{NAB}$ was that the stomach is the source of acid in the refluxate; suppression of gastric acid may reduce the injurious effect of the refluxate in GERD. To overcome short plasma half-life of PPIs, several pharmacological attempts have been made to control $\mathrm{NAB}$ with different regimens and doses of PPIs. In addition, investigators have also attempted to eliminate NAB by targeting the night time histamine surge, with administration of histamine $\mathrm{H} 2$ receptor antagonists (H2RA) (Table), ${ }^{2,4-12}$

What is the treatment effect of PPIs, which are known to have a longer plasma half-life on NAB? In this issue of the Journal of Neurogastroenterology and Motility, Karyampudi et al ${ }^{13}$ evaluated esophageal acidification during NAB with ilaprazole, versus omeprazole in patients with uncomplicated GERD, in a prospective manner. A total of 58 patients with GERD prescribed $10 \mathrm{mg}$ of ilaprazole or $20 \mathrm{mg}$ of omeprazole once daily for more than 1 month were enrolled in this study, and underwent 24-hour impedance$\mathrm{pH}$ monitoring. A total of $72.4 \%$ of patients had NAB. Despite the long-action of ilaprazole, its frequency, duration, and mean intra-gastric $\mathrm{pH}$ during $\mathrm{NAB}$, as well as nocturnal esophageal acidification and nocturnal symptoms were comparable between the

Received: March 14, 2017 Revised: None Accepted: March 14, 2017

(a) This is an Open Access article distributed under the terms of the Creative Commons Attribution Non-Commercial License (http://creativecommons. org/licenses/by-nc/4.0) which permits unrestricted non-commercial use, distribution, and reproduction in any medium, provided the original work is properly cited.

*Correspondence: Gwang Ha Kim, MD, PhD Department of Internal Medicine, Pusan National University School of Medicine, and Biomedical Research Institute, Pusan National University Hospital, 179, Gudeok-ro, Seo-gu, Busan 49241, Korea Tel: +82-51-240-7869, Fax: +82-51-244-8180, E-mail: doc0224@pusan.ac.kr 
Table. Summary of Published Studies About Management of Nocturnal Acid-breakthrough in Gastroesophageal Reflux Disease

\begin{tabular}{|c|c|c|c|}
\hline Authors & Year & Study design & Results \\
\hline 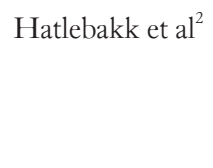 & 1998 & $\begin{array}{l}\text { Volunteers }(n=18) \\
\text { 1) OME } 40 \mathrm{mg} \text { qAM } \\
\text { 2) OME } 40 \mathrm{mg} \text { qPM } \\
\text { 3) OME } 20 \mathrm{mg} \text { bid }\end{array}$ & Split dosing was superior. \\
\hline Khoury et $\mathrm{al}^{4}$ & 1999 & $\begin{array}{l}\text { Volunteers }(n=21) \\
\text { 1) OME } 20 \mathrm{mg} \mathrm{AM}+\text { OME } 20 \mathrm{mg} \text { PM + placebo HS } \\
\text { 2) OME } 20 \mathrm{mg} \mathrm{AM}+\text { placebo PM + H2RA HS }\end{array}$ & $\begin{array}{l}\text { Bedtime H2RA did not replace an evening dose of } \\
\text { PPI in patients requiring more than a single daily } \\
\text { dose of PPI. }\end{array}$ \\
\hline Xue et $\mathrm{al}^{5}$ & 2001 & $\begin{array}{l}\text { GERD patients } \\
\text { 1) PPI bid }(n=60) \\
\text { 2) PPI bid }+ \text { H2RAs HS }(n=45) \\
\text { 3) Both regimen }(n=11)\end{array}$ & $\begin{array}{l}\text { A bedtime H2RA enhanced nocturnal gastric } \mathrm{pH} \\
\text { control and decreased esophageal acid exposure dur- } \\
\text { ing NAB. }\end{array}$ \\
\hline Fackler et $\mathrm{al}^{6}$ & 2002 & $\begin{array}{l}\text { Volunteers }(\mathrm{n}=18), \text { GERD patients }(\mathrm{n}=16) \\
\text { OME bid for } 2 \mathrm{wk} \\
\rightarrow \text { OME bid }+ \text { H2RA } 300 \mathrm{mg} \text { HS for } 28 \text { day }\end{array}$ & $\begin{array}{l}\text { Combination of H2RA and PPI reduced NAB only } \\
\text { with introduction of therapy (due to H2RA } \\
\text { tolerance). }\end{array}$ \\
\hline Orr et $\mathrm{al}^{7}$ & 2003 & $\begin{array}{l}\text { Symptomatic GERD patients }(\mathrm{n}=19) \\
\text { OME } 20 \mathrm{mg} \text { bid for } 1 \mathrm{wk} \\
+ \text { H2RA or placebo HS } \\
\text { + nighttime provocative reflux meal }\end{array}$ & $\begin{array}{l}\text { In spite of reduction of intragastric acidity, H2RA } \\
\text { had no effect on the occurrence of gastroesophageal } \\
\text { reflux during sleep. }\end{array}$ \\
\hline 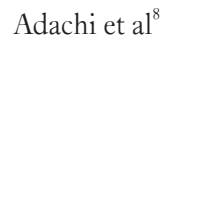 & 2003 & $\begin{array}{l}\text { Volunteers without } H \text {. pylori }(\mathrm{n}=10) \\
\text { 1) RAB } 20 \mathrm{mg} \text { qAM } \\
\text { 2) RAB } 20 \mathrm{mg} \text { qAM + H2RA HS (last day only) } \\
\text { 3) RAB } 20 \mathrm{mg} \text { qAM + continuous H2RA HS } \\
\text { 4) RAB } 10 \mathrm{mg} \text { bid }\end{array}$ & $\begin{array}{l}\text { Split dosing was better in gastric acid suppression. } \\
\text { Continuous H2RA was less effective. }\end{array}$ \\
\hline Shimatani et $\mathrm{al}^{9}$ & 2004 & $\begin{array}{l}\text { Volunteers without } H \text {. pylori }(n=18) \\
\text { 1) RAB } 10 \mathrm{mg} \mathrm{qAM} \\
\text { 2) RAB } 20 \mathrm{mg} \mathrm{qAM} \\
\text { 3) RAB } 10 \mathrm{mg} \text { bid }\end{array}$ & $\begin{array}{l}\text { Split dosing was more potent and long-lasting acid } \\
\text { suppression. }\end{array}$ \\
\hline Hammer et $\mathrm{al}^{10}$ & 2004 & $\begin{array}{l}\text { Volunteer }(n=13) \\
\text { 1) ESM } 20 \mathrm{mg} \text { bid } \\
\text { 2) ESM } 40 \mathrm{mg} \mathrm{qAM}\end{array}$ & Split dosing improved nighttime acid suppression. \\
\hline Katz et $\mathrm{al}^{11}$ & 2007 & $\begin{array}{l}\text { Nocturnal GERD patients }(n=54) \\
\text { 1) IR-OME } 40 \mathrm{mg} \text { HS } \\
\text { 2) LPZ } 30 \mathrm{mg} \text { HS } \\
\text { 3) ESM } 40 \mathrm{mg} \text { HS }\end{array}$ & $\begin{array}{l}\text { Bedtime dosing with IR-OME was effective with } \\
\text { night-time heartburn. }\end{array}$ \\
\hline Mainie et $\mathrm{al}^{12}$ & 2008 & $\begin{array}{l}\text { GERD patients }(n=100) \\
\text { 1) PPI bid }(n=58) \\
\text { 2) PPI bid + H2RA HS }(n=42)\end{array}$ & $\begin{array}{l}\text { A bedtime } \mathrm{H} 2 \mathrm{RA} \text { reduced the percentage time of the } \\
\text { intragastric } \mathrm{pH}<4 \text { and also NAB. }\end{array}$ \\
\hline
\end{tabular}

OME, omeprazole; qAM, once daily before breakfast; qPM, once daily before dinner; bid, twice a day; HS, at bed time; H2RA, histamine H2 receptor antagonist; PPI, proton pump inhibitor; GERD, gastroesophageal reflux disease; NAB, nocturnal acid-breakthrough; H. pylori, Helicobacter pylori; RAB, rabeprazole; ESM, esomeprazole; IR-OME, immediate release omeprazole; LPZ, lansoprazole.

ilaprazole and omeprazole groups. Among those who had NAB, a lesser number of NAB episodes occurred in the ilaprazole group compared to the omeprazole group $(P=0.010)$. On the contrary, a previous study showed that $20 \mathrm{mg}$ of ilaprazole provided significantly higher mean 24-hour intragastric $\mathrm{pH}$ than the same dose of omeprazole and that low-dose ilaprazole (5 $\mathrm{mg}$ and $10 \mathrm{mg}$ ) offered a gastric acid inhibition comparable to a routine dose of omepra- zole. ${ }^{14} \mathrm{In}$ another study, $10 \mathrm{mg}$ or higher of ilaprazole may provide better control of $\mathrm{NAB}$, nocturnal esophageal acidification, and nocturnal symptoms. ${ }^{13}$

Another important thing in this study was that the authors evaluated the clinical significance of NAB. The frequency and duration of nocturnal esophageal acidification and nocturnal symptoms were comparable with or without NAB. Regarding specific conditions 
such as Barrett's esophagus, ineffective esophageal motility, and complicated GERD including high-grade erosive reflux disease, NAB has been reported to be more likely accompanied by esophageal reflux. ${ }^{15-19}$ Therefore, if patients with these conditions show resistance to PPI treatment, the existence of NAB with nocturnal acid reflux should be considered. Otherwise, several previous studies suggested that NAB did not correlate well with esophageal acid exposure or nocturnal reflux symptom..$^{20-22}$ Ours et $\mathrm{al}^{22}$ reported that all subjects, whether treated with a PPI or a PPI plus H2RA, and regardless of drug schedule, were asymptomatic after treatment despite the presence of $\mathrm{NAB}$; they concluded that $\mathrm{NAB}$ is a purely gastric phenomenon with no correlation to esophageal acid levels or symptom improvement.

In regards to uncomplicated GERD patients who have particularly normal esophageal clearance mechanisms, the clinical importance of NAB is likely to be little. NAB is common during administration of PPIs, and identification of esophageal acidification and nocturnal symptoms are essential to evaluate the "real" clinical effect of PPIs on GERD, not intragastric $\mathrm{pH}$.

\section{Financial support: None.}

\section{Conflicts of interest: None.}

Author contributions: Hye Kyung Jeon drafted and edited; and Gwang Ha Kim revised and performed the final approval of the manuscript.

\section{References}

1. Vakil N, van Zanten SV, Kahrilas P, Dent J, Jones R; Global Consensus Group. The Montreal definition and classification of gastroesophageal reflux disease: a global evidence-based consensus. Am J Gastroenterol 2006;101:1900-1920.

2. Hatlebakk JG, Katz PO, Kuo B, Castell DO. Nocturnal gastric acidity and acid breakthrough on different regimens of omeprazole $40 \mathrm{mg}$ daily. Aliment Pharmacol Ther 1998;12:1235-1240.

3. Peghini PL, Katz PO, Bracy NA, Castell DO. Nocturnal recovery of gastric acid secretion with twice-daily dosing of proton pump inhibitors. Am J Gastroenterol 1998;93:763-767.

4. Khoury RM, Katz PO, Hammod R, Castell DO. Bedtime ranitidine does not eliminate the need for a second daily dose of omeprazole to suppress nocturnal gastric $\mathrm{pH}$. Aliment Pharmacol Ther 1999;13:675-678.

5. Xue S, Katz PO, Banerjee P, Tutuian R, Castell DO. Bedtime H2 blockers improve nocturnal gastric acid control in GERD patients on proton pump inhibitors. Aliment Pharmacol Ther 2001;15:1351-1356.

6. Fackler WK, Ours TM, Vaezi MF, Richter JE. Long-term effect of
H2RA therapy on nocturnal gastric acid breakthrough. Gastroenterology 2002;122:625-632.

7. Orr WC, Harnish MJ. The efficacy of omeprazole twice daily with supplemental $\mathrm{H} 2$ blockade at bedtime in the suppression of nocturnal oesophageal and gastric acidity. Aliment Pharmacol Ther 2003;17:15531558.

8. Adachi K, Komazawa Y, Fujishiro H, et al. Nocturnal gastric acid breakthrough during the administration of rabeprazole and ranitidine in Helicobacter pylori-negative subjects: effects of different regimens. J Gastroenterol 2003;38:830-835.

9. Shimatani T, Inoue M, Kuroiwa T, Horikawa Y. Rabeprazole $10 \mathrm{mg}$ twice daily is superior to $20 \mathrm{mg}$ once daily for night-time gastric acid suppression. Aliment Pharmacol Ther 2004;19:113-122.

10. Hammer J, Schmidt B. Effect of splitting the dose of esomeprazole on gastric acidity and nocturnal acid breakthrough. Aliment Pharmacol Ther 2004;19:1105-1110.

11. Katz PO, Koch FK, Ballard ED, et al. Comparison of the effects of immediate-release omeprazole oral suspension, delayed-release lansoprazole capsules and delayed-release esomeprazole capsules on nocturnal gastric acidity after bedtime dosing in patients with night-time GERD symptoms. Aliment Pharmacol Ther 2007;25:197-205.

12. Mainie I, Tutuian R, Castell DO. Addition of a $\mathrm{H} 2$ receptor antagonist to PPI improves acid control and decreases nocturnal acid breakthrough. J Clin Gastroenterol 2008;42:676-679.

13. Karyampudi A, Ghoshal UC, Singh R, Verma A, Misra A, Saraswat VA. Esophageal acidification during nocturnal acid-breakthrough with ilaprazole versus omeprazole in gastroesophageal reflux disease. J Neurogastroenterol Motil 2017;23:208-217.

14. Du YQ, Guo WY, Zou DW, et al. Acid inhibition effect of ilaprazole on Helicobacter pylori-negative healthy volunteers: an open randomized cross-over study. J Dig Dis 2012;13:113-119.

15. Katz PO, Anderson C, Khoury R, Castell DO. Gastro-oesophageal reflux associated with nocturnal gastric acid breakthrough on proton pump inhibitors. Aliment Pharmacol Ther 1998;12:1231-1234.

16. Fouad YM, Katz PO, Castell DO. Oesophageal motility defects associated with nocturnal gastro-oesophageal reflux on proton pump inhibitors. Aliment Pharmacol Ther 1999;13:1467-1471.

17. Adachi K, Fujishiro H, Katsube T, et al. Predominant nocturnal acid reflux in patients with Los Angeles grade $\mathrm{C}$ and $\mathrm{D}$ reflux esophagitis. J Gastroenterol Hepatol 2001;16:1191-1196.

18. Yeh RW, Gerson LB, Triadafilopoulos G. Efficacy of esomeprazole in controlling reflux symptoms, intraesophageal, and intragastric $\mathrm{pH}$ in $\mathrm{pa}-$ tients with Barrett's esophagus. Dis Esophagus 2003;16:193-198.

19. Janiak P, Thumshirn M, Menne D, et al. Clinical trial: the effects of adding ranitidine at night to twice daily omeprazole therapy on nocturnal acid breakthrough and acid reflux in patients with systemic sclerosis--a randomized controlled, cross-over trial. Aliment Pharmacol Ther 2007;26:1259-1265

20. Ghoshal UC, Chourasia D, Tripathi S, Misra A, Singh K. Relationship of severity of gastroesophageal reflux disease with gastric acid secretory profile and esophageal acid exposure during nocturnal acid breakthrough: a study using 24-h dual-channel pH-metry. Scand J Gastroenterol 
2008;43:654-661.

21. Weigt J, Kandulski A, Büsch F, Malfertheiner P. Nocturnal gastric acid breakthrough is not associated with night-time gastroesophageal reflux in GERD patients. Dig Dis 2009;27:68-73.
22. Ours TM, Fackler WK, Richter JE, Vaezi MF. Nocturnal acid breakthrough: clinical significance and correlation with esophageal acid exposure. Am J Gastroenterol 2003;98:545-550. 